\title{
ANALISIS PENGARUH EKONOMI MAKRO DAN INDEKS BURSA DUNIA TERHADAP INDEKS HARGA SAHAM GABUNGAN (IHSG)
}

\section{Farhan Hardianto Putra, Marseto, Sishadiyati}

Universitas Pembangunan Nasional (UPN) Veteran Jawa Timur, Indonesia

Email: farhanhard.16@gmail.com,marseto15@gmail.com, sishadiyati.ep@upnjatim.ac.id

\begin{abstract}
Abstrak
Indeks Harga Saham Gabungan (IHSG) bisa dibilang sebagai pandangan pergerakan saham dikarenakan indeks ini mencakup seluruh saham yang terdaftar di Bursa Efek Indonesia (BEI). Indeks Harga Saham Gabungan (IHSG) dipengaruhi oleh beberapa faktor, yaitu faktor internal dan eksternal. Penelitian ini bertujuan untuk mengetahui pengaruh nilai tukar rupiah terhadap US Dollar,BI Rate, Indeks Dow Jones, dan Indeks Nikkei 225 terhadap Indeks Harga Saham Gabungan (IHSG) di Bursa Efek Indonesia (BEI) pada periode 2017-2019 dalam periode bulanan. Data sekunder yang digunakan oleh peneliti diperoleh melalui Website Bank Indonesia (BI), Bursa Efek Indonesia (BEI), dan Investing.com. Metode Penelitian kuantitatif dipakai dengan menggunakan Analisis Regresi Linear Berganda dengan model Ordinary Least Square (OLS). Tujuan dari penelitian ini untuk mengetahui apa saja yang mempengaruhi Indeks Harga Saham Gabungan (IHSG) karena IHSG juga termasuk pandangan perekonomian Indonesia. Dapat disimpulkan bahwa nilai tukar Rupiah terhadap US Dollar tidak berpengaruh secara signifikan dikarenakan dilihat dari nilai signifikansinya yaitu 0,079. Variabel BI Rate juga belum bisa mempengaruhi IHSG karena mempunayi nilai signifikansi sebesar 0,541. Indeks Nikkei 225 tidak berpengaruh signifikan terhadap Indeks Harga Saham Gabungan (IHSG) dikarenakan memiliki nilai signifikansi sebesar 0,550. Sedangkan Indeks Dow Jones berperngaruh signifikan Indeks Harga Saham Gabungan (IHSG) dengan nilai signifikansi sebesar 0,000 dan menjadi satu-satunya variabel yang berpengaruh terhadap IHSG.
\end{abstract}

Kata Kunci: indeks harga saham gabungan; nilai tukar; bi rate; indeks dow jones; indeks nikkei 22

\section{Abstract}

Indonesian Composite Index (ICI) can be considered as a view of stock movements because this index covers all stocks listed on the Indonesia Stock Exchange (IDX). The Composite Stock Price Index (JCI) is influenced by several factors, namely internal and external factors. This study aims to determine the effect of the rupiah exchange rate on the US Dollar, BI Rate, Dow Jones Index, and Nikkei 225 Index on the Indonesian Composite Index (ICI) on the Indonesia Stock Exchange (IDX) in the 2017-2019 period in a monthly period. The secondary data used by the researcher was obtained through the Website of Bank Indonesia (BI), the Indonesia Stock Exchange (IDX), and Investing.com. Quantitative research method is used by

$\begin{array}{ll}\text { How to cite: } & \text { Putra, Farhan Hardianto, Marseto dan Sishadiyati (2021) Analisis Pengaruh Ekonomi Makro dan } \\ & \begin{array}{l}\text { Indeks Bursa Dunia Terhadap Indeks Harga Saham Gabungan (IHSG), Syntax Idea, 3(7). https:// } \\ \text { doi.org/10.36418/syntax-idea.v3i7.1333 }\end{array} \\ \text { E-ISSN: } & \text { 2684-883X } \\ \text { Published by: } & \text { Ridwan Institute }\end{array}$


using Multiple Linear Regression Analysis with Ordinary Least Square (OLS) model. The purpose of this study is to find out what influences the Indonesian Composite Index (ICI) because the ICI also includes the view of the Indonesian economy. It can be concluded that the exchange rate of the Rupiah against the US Dollar has no significant effect because it is seen from the significance value of 0.079. The BI Rate variable also has not been able to influence the ICI because it has a significance value of 0.541. The Nikkei 225 index has no significant effect on the Indonesian Composite Index (ICI)because it has a significance value of 0.550 . Meanwhile, the Dow Jones Index has a significant effect on Indonesian Composite Index (ICI) with a significance value of 0.000 and is the only variable that has an effect on the ICI.

Keywords: composite stock price index; exchange rate; bi rate; dow jones index; nikkei index 22

\section{Pendahuluan}

Perekonomian dunia dipengaruhi oleh perkembangan ekonomi negara lain maupun kerja sama ekonomi antar negara seperti menanam investasi di negara lain. Investasi keuangan bisa diaplikasikan ke pasar modal dan mempunyai pengaruh terhadap perekonomian keselurahan suatu negara dikarenakan meningkatnya output nasional (Utama \& Artini, 2015). Instrumen pasar modal menjadi salah satu instrumen investasi yang sering dipakai oleh investor. Di zaman sekarang mencari informasi yang lebih lengkap bagi para investor tentang perkembangan bursa sangatlah gampang karena Bursa Efek Indonesia menyediakan data-data pergerakan harga saham melalui media cetak maupun elektronik. Pasar modal di Indonesia yang dibawahi oleh Bursa Efek Indonesia (BEI) yang berperan sebagai perantara investor dengan perusahaan emiten. Indeks yang dipakai oleh BEI yaitu Indeks Harga Saham Gabungan atau IHSG. Investor selalu memperhatikan Indeks Harga Saham Gabungan (IHSG) untuk memantau pergerakan saham dikarenakan indeks ini mencakup seluruh saham yang terdaftar di Bursa Efek Indonesia (BEI) (Ernayani, 2015).

Pergerakan Indeks Harga Saham Gabungan (IHSG) dipengaruhi oleh beberapa faktor, faktornya bisa dibagi menjadi dua yaitu faktor eksternal dan internal (Wibowo, Arifati, \& Raharjo, 2016). Faktor eksternal yang digunakan adalah Indeks Dow Jones dan Indeks Nikkei 225. Indeks Dow Jones adalah sebuah indeks harga saham yang dipakai oleh Amerika Serikat sebagai acuan untuk melihat performa perusahaan di pasar modal (Agus, Utama, Gede, \& Artini, 2015). Indeks Dow Jones memberikan pengaruh dikarenakan Amerika Serikat termasuk salah satu negara yang tergolong maju. Pertumbuhan negara maju pada dasarnya mempunyai hubungan dengan negara berkembang (Yusnita Jayanti, 2014). Indeks Dow Jones mampu menggambarkan kondisi perekonomian yang sedang terjadi di Amerika (Bodie, Kane, \& Marcus, 2014). Pada saat Indeks Dow Jones mengalami peningkatan maka perekonomian Amerika Serikat sedang membaik. Hubungannya dengan Indeks Harga Saham Gabungan (IHSG) adalah Amerika Serikat merupakan tujuan ekspor bagi negara Indonesia jadi jika pertumbuhan ekonomi Amerika Serikat mengalami peningkatan maka faktor itu bisa 
mendorong pertumbuhan ekonomi Indonesia melalu kegiatan ekspor ,investasi langsung,maupun melalui investasi pada pasar modal sehingga Indeks Harga Saham Gabungan (IHSG) mengalami peningkatan (Yusnita Jayanti, 2014). Faktor eksternal yang kedua yaitu Indeks Nikkei 225. Jepang adalah salah satu negara yang tergolong maju dan bisanya negara maju bisa mempengaruhi negara berkembang maka dari itu Jepang adalah salah satu negara tujuan ekspor Indonesia. Peningkatan kinerja perekonomian Jepang Sebagai salah satu negara tujuan ekspor Indonesia, pertumbuhan ekonomi Jepang dapat mendorong pertumbuhan ekonomi Indonesia melalui kegiatan ekspor maupun aliran modal masuk baik investasi langsung maupun melalui pasar modal (Yusnita Jayanti, 2014). Setiap peristiwa yang terjadi di TSE (Tokyo Stock Exchange) memberikan dampak atas perhitungan indeks dan bilangan pembaginya atau divisor dan iuntuk Metode perhitungannya menggunakan perhitungan harga rata-rata (unit dalam yen), dan komponennya ditinjau ulang setahun sekali (Bagus Setiawan, 2014).

Permasalahan faktor-faktor yang mempengaruhi Indeks Harga Saham Gabungan adalah masalah utama bagi para investor dan juga perekonomian negara yang seharusnya bisa diminimalisir untuk kesejahteraan para investor dan ekonomi suatu negara. Oleh karena itu peneliti mengambil permasalahan ini guna untuk mengetahui apa saja faktor-faktor yang mempengaruhi Indeks Harga Saham Gabungan (IHSG) dari faktor internal dan eksternal.

Dua faktor internal dalam penelitian ini bisa mempengaruhi Indeks Harga Saham Gabungan (IHSG) yaitu BI Rate dan nilai tukar kurs dimana BI Rate sebagai variabel dalam penelitian ini BI mempunyai pengaruh kondisi Indeks Harga Saham Gabungan (IHSG) di BEI dengan BI Rate yang tinggi mampu mendorong investor untuk memindahkan dananya dari saham ke instrumen yaitu dalam bentuk tabungan atau deposito (Wibowo et al., 2016). Peningkatan Suku Bunga SBI mempunyai pengaruh terhadap suku bunga simpanan yang juga mengalami peningkatan membuat investor mempunyai ketertarikan berinvestasi di pasar uang dari pada berinvestasi di pasar saham (Amin, 2012). Kondisi BI Rate yang tinggi akan memicu penurunan terhadap pergerakan nilai IHSG di bursa saham (Wibowo et al., 2016). Sebaliknya apabila BI Rate mengalami penurunan maka investor akan kembali berinvestasi pada pasar modal, karena posisi IHSG mengalami peningkatan (Wibowo et al., 2016). Faktor selanjutnya yaitu nlai tukar dimana nilai tukar Rupiah terdepresiasi dalam mata uang asing, sehingga berpengaruh terhadap perusahaan yang melakukan ekspor dan impor (Hasyim, 2019). Kebanyakan perusahaan di Indonesia menggunakan bahan pokok produksi mengambil dari negara lain sehingga menyebabkan meningkatnya biaya produksi perusahaan (Nurhayati, Mardani, \& Mustapita, 2020). Peningkatan biaya produksi dapat menyebabkan pengurangan laba suatu perusahaan. Menurunnya laba perusahaan akan berpengaruh pada laporan keuangan, sehingga minat investor untuk berinvestasi di perusahaan tersebut akan menurun dan berpengaruh buruk terhadap Indeks Harga Saham Gabungan (IHSG) (Nurhayati et al., 2020). 
Variabel ekonomi suatu negara yang mengalami perubahan dan perkembangan akan sangat berpengaruh dalam kegiatan di bidang pasar modal. Buruknya kinerja variabel ekonomi makro akan berdampak negatif juga di dunia pasar modal. Sebaliknya jika variabel ekonomi makro kinerjanya baik maka dunia pasar modal juga akan baik bagi para investor, jadi bisa dibilang kinerja ekonomi makro akan berpengaruh sama dengan pasar modal. IHSG tidak hanya berhubungan peristiwa ekonomi, tetapi lebih jauh lagi juga menampung peristiwa sosial (Wibowo et al., 2016).

Penelitian terdahulu bertujuan untuk mengetahui bahan dan acuan yang pada dasarnya untuk menghindari persamaan dengan penelitian yang lain seperti dalam penelitian (Y. Jayanti, 2014) yang menjelaskan bahwa BI Rate dan nilai tukar rupiah mempunyai pengaruh negatif dan signifikan, sedangkan Indeks Dow Jones mempunyai pengaruh positif terhadap IHSG. Penelitian dari (Ernayani, 2015) yang dalam penelitiannya mempunyai hasil untuk variabel Kurs Dollar tidak mempunyai pengaruh terhadap Indeks Harga Saham Gabungan, sedangkan Indeks Dow Jones mempunyai pengaruh positif bagi Indeks Harga Saham Gabungan (IHSG). Suku Bunga SBI sendiri mempunyai pengaruh negatif terhadap Indeks Harga Saham Gabungan (IHSG).

Tujuan dari penelitian ini untuk mengetahui apa saja yang mempengaruhi Indeks Harga Saham Gabungan (IHSG) karena IHSG juga termasuk pandangan perekonomian Indonesia sehingga kita harus tau solusi untuk menghindari dari faktor-faktor negatif.

\section{Metode Penelitian}

Teknik pengumpulan data yang digunakan dalam penelitian ini adalah metode dokumentasi yaitu teknik pengumpulan data yang diperoleh dengan cara mengambil data dari catatan yang dilakukan secara sistematis terhadap fenomena tertentu dari suatu objek yang diteliti, atau disebut data sekunder. Penelitian ini menggunakan data sekunder dari website resmi Bank Indonesia (www.bi.go.id) meliputi data tingkat inflasi, tingkat suku bunga SBI, nilai tukar Rupiah, dan website www.investing.com yang meliputi data indeks Dow Jones, indeks Nikkei 225 dan Indeks Harga Saham Gabungan (IHSG).

Data yang sudah dikumpulkan dianalisis dengan metode analisis linier berganda dengan model Ordinary Least Square (OLS). Analisis Regresi Linier Berganda bisa digunakan untuk mengetahui hubungan antara variabel bebas terhadap variabel terikat positif atau negatif (Sudarsana \& Candraningrat, 2014). Bentuk umum model regresi linier berganda untuk populasi dapat ditunjukkan sebagi berikut (Nachrowi \& Usman, 2005):

Keterangan:

$$
\mathrm{Y}=\beta 0+\beta 1 \mathrm{X} 1+\beta 2 \mathrm{X} 2+\beta 3 \mathrm{X} 3+\beta 4 \mathrm{X} 4+\mathrm{e}
$$

Y= Indeks Harga Saham Gabungan (IHSG)

$\alpha=$ Konstanta 
$\beta 1-\beta 4=$ Koefisien regresi berganda

$\mathrm{X} 1=$ Nilai tukar kurs

$\mathrm{X} 2=$ Suku bunga SBI

$\mathrm{X} 3=$ Indeks Dow Jones

X4= Indeks Nikkei 225

\section{Hasil dan Pembahasan}

\section{A. Hasil Penelitian}

\section{Deskripsi Data}

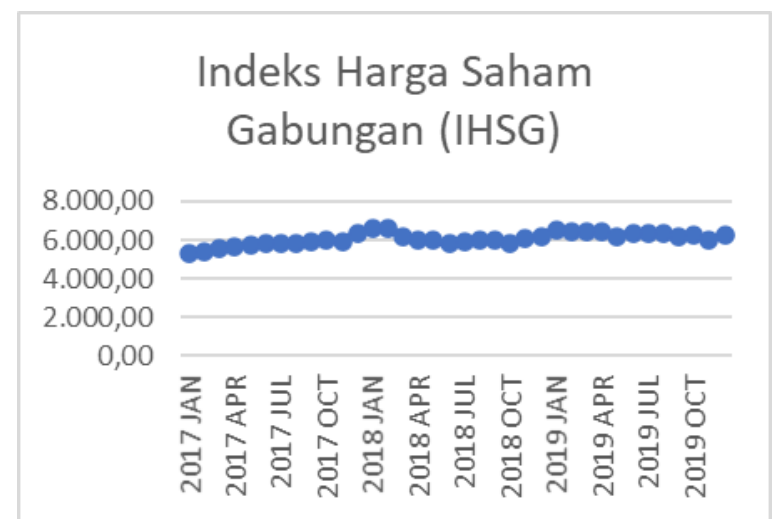

Data Indeks Harga Saham Gabungan

Indeks Harga Saham Gabungan (IHSG) mempunyai kegunaan untuk menghitung rata-rata semua saham yang berada di Bursa Efek Indonesia (BEI) (Arifin, 2014). Berdasarkan gambar di atas pada saat mendekati tahun baru yang tepatnya pada bulan Desember ke Januari sering terjadi kenaikan seperti pada tahun 2018 dan 2019. Fenomena kenaikan Indeks Harga Saham Gabungan (IHSG) pada bulan Desember bisa disebut sebagai istilah Santa Claus Rally yang berarti sebuah fenomena yang terjadi dikarenakan meningkatnya pembelian saham pada dua minggu terakhir di bulan Desember atau lebih tepatnya pada saat perayaan hari natal. Fenomena ini ada dikarenakan akan terjadi January effect dimana investor banyak yang menjual saham sehingga dapat menaikkan harga saham yang rendah.

Setelah Santa Claus Effect selanjutnya ada fenomena berikutnya yaitu January Effect. January Effect terjadi karena adanya pola kondisi pasar modal yang dimana harga saham meningkat pada dua minggu pertama di bulan Januari. Fenomena ini juga bisa disebabkan oleh perilaku para investor yang pada umumnya dikarenakan masalah pajak sehingga menjual saham-saham yang merugi atau yang kurang menguntungkan pada akhir tahun kemudian membelinya kembali pada awal bulan Januari. 


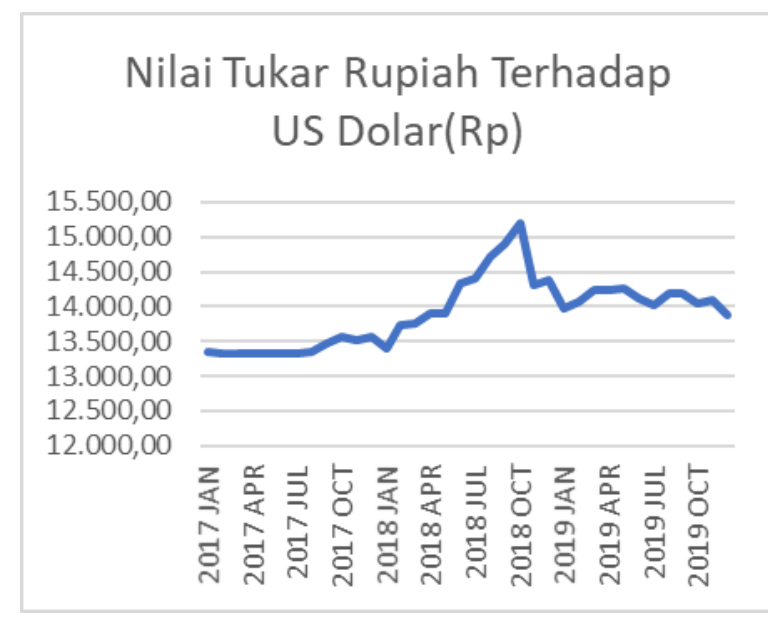

\section{Gambar 1 \\ Data Nilai Tukar Rupiah Terhadap US Dollar}

Berdasarkan gambar diatas pada tahun 2018 Rupiah berada disekitar Rp13.413-Rp15.227 per Dollar AS dengan fluktuatif dan cenderung melemah di sepanjang tahun 2018 sehingga akan memperburuk keadaan perekonomian di Indonesia. Penguatan Rupiah di awal-awal tahun 2018 di dorong oleh aliran modal asing yang masuk dan sejalan dengan persepsi positif investor terhadap perekonomian domestik. Penurunan nilai Rupiah terus berjalan hingga akhir tahun dikarenakan data ekonomi AS yang memperkuat assesment bank sentral AS dimana pasar tenaga kerja yang naik serta meningkatnya investasi.

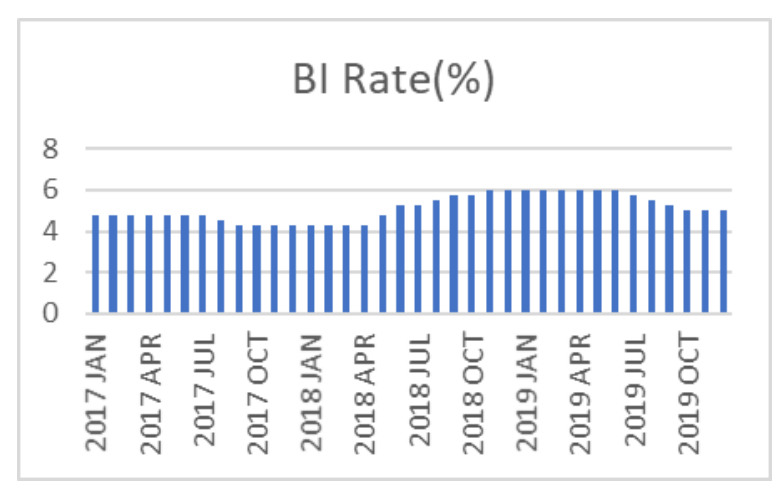

\section{Gambar 2}

\section{Data BI Rate}

Pada tahun 2018 Bank Indonesia (BI) menaikkan BI 7-day Reverse Report Rate sebesar 25 basis poin $(0,25 \%)$. Artinya saat ini suku bunga acuan BI adalah sebesar 6,00\%. Kenaikan suku bunga tersebut dilakukan sebagai langkah lanjutan Bank Indonesia untuk memperkuat upaya menurunkan defisit transaksi berjalan (curent account defisit/CAD) ke dalam batas aman. Maka dari itu pada tahun 2018 Bi Rate meningkat mencapai $6,00 \%$. 


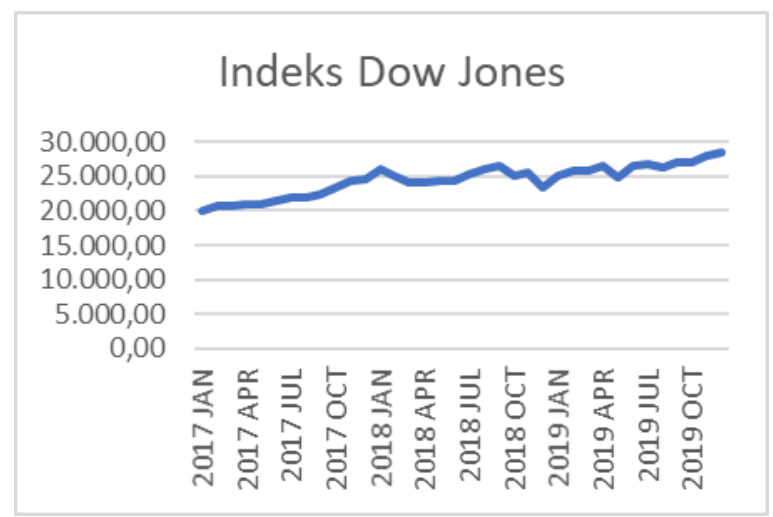

\section{Gambar 3}

Data Indeks Dow Jones

Indeks Dow Jones juga digunakan sebagai salah satu faktor dari kinerja perekonomian Amerika Serikat (Ernayani, 2015). Indeks Dow Jones mengalami peningkatan maka perekonomian Amerika Serikat sedang membaik. Sejak Mei 2018 Indeks Dow Jones mencatatkan kenaikan terpanjangnya dalam 13 bulan setelah pemerintah AS membatalkan rencana untuk mengenakan tarif pada barang-barang Meksiko. Pada periode 20172019 bisa dilihat bahwa grafiknya selalu meningkat.

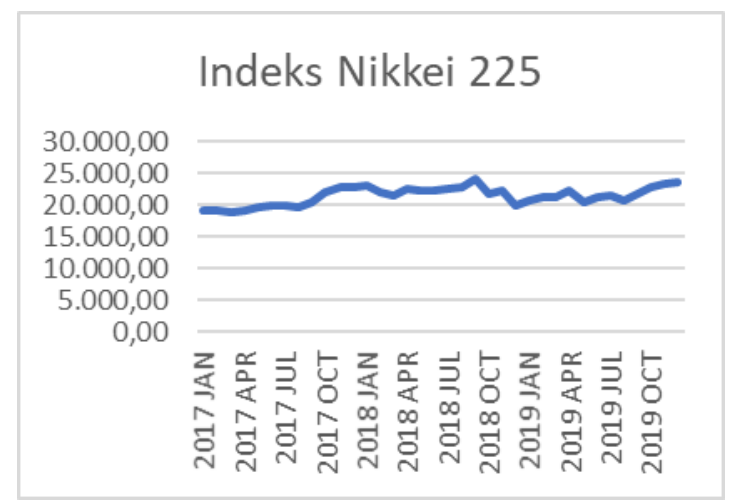

\section{Gambar 4}

\section{Data Indeks Nikkei 225}

Nikkei adalah indeks harga tertimbang; saham yang diperdagangkan dengan harga $\$ 50$ akan menghasilkan 5 kali lebih banyak dari total saham yang diperdagangkan dengan harga $\$ 10$. Ini membuat perusahaanperusahaan besar lebih berpengaruh pada pergerakan indeks. Indeks Nikkei 225 telah menguat lebih dari $6 \%$ tahun ini, didorong oleh penguatan produsen obat, peritel dan saham defensif lainnya. dengan perusahaan seperti Family Mart UNY Holding dan Eisai Co (Indexes.nikkei.co.jp, n.d.). 
Maka dari itu pada tahun 2018 nikkei mengalami peningkatan 24.120,04 pada bulan September 2018.

2. Hasil Uji Asumsi Klasik (BLUE / Best Linear Unbiased Estimator)

a. Uji Normalitas

Tabel 1

Uji Normalitas

\begin{tabular}{llr}
\hline \multicolumn{3}{c}{ One-Sample Kolmogorov-Smirnov Test } \\
\hline & & Unstandardized Residual \\
\hline $\mathrm{N}$ & & 36 \\
\hline Normal & Mean & .0000000 \\
\cline { 2 - 3 } Parameters $^{\text {a,b }}$ & Std. Deviation & 196.69435314 \\
\hline Most & Absolute & .108 \\
\cline { 2 - 3 } Extreme & Positive & .108 \\
\cline { 2 - 3 } Differences & Negative &. .096 \\
\hline Test Statistic & & .108 \\
\hline Asymp. Sig. (2-tailed) & $.200^{\text {c,d }}$ \\
\hline
\end{tabular}

Uji Normalitas digunakan untuk menguji apakah variabel dependen dan independen dalam penelitian ini layak untuk dipakai atau normal menggunakan One Sample Solgomorov Sminov Test (Ghozali, 2016). Dasar pengembalian keputusan adalah jika Sig 2-tailed > 0,05, maka model regresi memenuhi asumsi normalitas dan sebaliknya.

Nilai signifikan residual yaitu 0,200 > 0,05 maka dapat disimpulkan bahwa data terdistribusi secara normal. Selain itu grafik uji P-P Plot dapat dilihat dibawah ini.

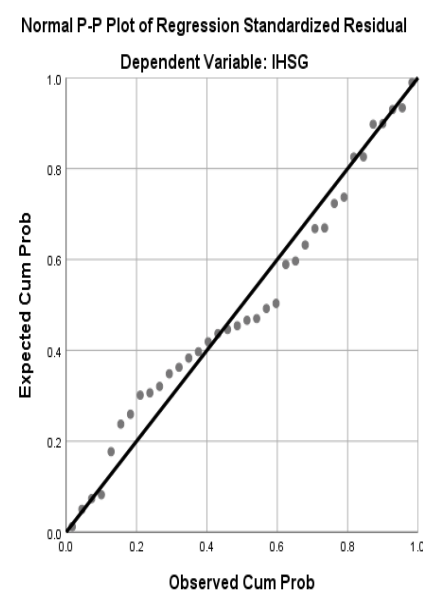

Gambar 5

Uji P-P Plot

Pengujian P-P Plot diatas sebaran data (titik) pada grafik diagonal tersebar di sekeliling garis diagonal atau histogramnya, yang berarti menjelaskan pola sebaran normal. 


\section{b. Uji Autokorelasi}

Penelitian ini dilakukan uji autokorelasi dan didapat nilai uji DW sebesar 0,589. Dari kurva diatas dapat dijelaskan bahwa nilai DW test berada sebelum di titik dL yang berarti data yang digunakan terjadi autokorelasi positif maka dari itu untuk memastikan lagi bahwa data dalam penelitian ini terkena auto korelasi atau tidak makan akan dilakukannya uji run test. Uji run test menunjukkan nilai signifikan sebesar 0,063>0,05 sehingga bisa disimpulkan dari hasil uji run test bahwa data tidak terjadi autokorelasi.

\section{c. Uji Multikolinieritas}

Maka hasil yang diperoleh setelah diadakan pengujian analisis regresi linier berganda diketahui bahwa dari keempat variabel independen Nilai tukar $(4,088)$, BI Rate (4,307),Indeks Dow Jones (5,463), dan Indeks NIkkei 225 $(6,235)$ dalam pengujian nilai Indeks Harga Saham Gabungan, dimana nilai VIF lebih kecil dari 10 sehingga dalam model regresi ini tidak terjadi multikolinieritas.

\section{d. Uji Heterokedastisitas}

Diperoleh tingkat signifikansi koefisien korelasi Rank Spearman untuk variabel terikat IHSG, keseluruhan residualnya lebih besar dari 0,05 (tidak signifikan) yaitu X1 (0,444), X2 (0,708), X3 (0,216), dan X4 (0,756). Hal tersebut menunjukkan bahwa antara nilai residual dengan variabel yang menjelaskan tidak mempunyai korelasi yang berarti. Jadi dapat disimpulkan persamaan tersebut tidak terjadi heterokedastisitas.

\section{e. Uji Koefisien Determinasi $\left(\mathbf{R}^{2}\right)$}

Hasil pengolahan data tersebut diketahui bahwa nilai koefisien determinasi sebesar 0,629 artinya 62,9\% dari seluruh pengamatan menunjukkan variabel bebas nilai tukar (X1), BI Rate (X2), Indeks Dow Jones (X3), dan Indeks Nikkei 225 (X4) mampu menjelaskan variasi variabel terikatnya yaitu Indeks Harga Saham Gabungan (Y), sisanya 37,1\% dipengaruhi faktor lain diluar model.

\section{f. Uji F}

Diperoleh nilai $\mathrm{F}$ hitung sebesar 13.148 dengan tingkat signifikasi sebesar $0,000 \mathrm{~b}$ dengan taraf signifikasi $5 \%$ atau $(\alpha=0,05)$ maka nilai sig $0,000<0,05$. Sedangkan nilai $\mathrm{F}$ tabel dengan degree of freedom (df1) adalah 4 (jumlah variabel bebas/k) dan df2 31 (n-k-1) diperoleh nilai F tabel sebesar 2,679. Dari hasil tersebut diketahui bahwa nilai F hitung 13,148 $\geq \mathrm{F}$ tabel 2,679 sehingga $\mathrm{H} 0$ ditolak dan Hi diterima, Maka dapat disimpulkan secara bersama-sama Nilai tukar, BI Rate, Indeks Dow Jones, dan Indeks Nikkei 225 berpengaruh positif terhadap Indeks Harga Saham Gabungan (IHSG).

\section{g. Uji T}

Uji T digunakan untuk melihat pengaruh variabel X1 (Nilai Tukar), X2 (BI Rate), X3 (Indeks Dow Jones), dan X4 (Indeks Nikkei 225) terhadap variabel Y (Indeks Harga Saham Gabungan) secara parsial dengan nilai signifikan sebesar 0,05 . 
Dari perhitungan secara parsial diperoleh nilai $\mathrm{t}$ hitung sebesar 1,815 sedangkan nilai sig $(\alpha / 2=0,025)$ dengan degree of freedom (df) 31 (n-k-1) diperoleh nilai $\mathrm{t}$ tabel sebesar 1,695. Dari hasil tersebut diketahui bahwa nilai $\mathrm{t}$ hitung $-1,815 \leq \mathrm{t}$ tabel 1,695 maka H0 diterima dan Hi ditolak, dengan nilai signifikansi $0,079>0,05$.

Dari perhitungan secara parsial diperoleh nilai t hitung sebesar 0,617 sedangkan nilai sig $(\alpha / 2=0,025)$ dengan degree of freedom (df) 31 (n-k-1) diperoleh nilai t tabel sebesar 1,695. Dari hasil tersebut diketahui bahwa nilai $\mathrm{t}$ hitung $0,617 \leq \mathrm{t}$ tabel 1,695 maka $\mathrm{H} 0$ diterima dan Hi ditolak, dengan nilai signifikansi 0,541 >0,05. kurva Uji t diatas berada pada daerah penerimaan $\mathrm{H} 0$ maka dapat disimpulkan secara parsial variabel BI Rate tidak berpengaruh signifikan terhadap Indeks Harga Saham Gabungan (IHSG).

Dari perhitungan secara parsial diperoleh nilai t hitung sebesar 4.169 sedangkan nilai sig $(\alpha / 2=0,025)$ dengan degree of freedom (df) 31 (n-k-1) diperoleh nilai t tabel sebesar 1,695. Dari hasil tersebut diketahui bahwa nilai $t$ hitung $4.169>\mathrm{t}$ tabel 1,695 maka $\mathrm{H} 0$ ditolak dan $\mathrm{H} 1$ diterima, dengan nilai signifikansi $0,000<0,05$. kurva Uji t diatas berada pada daerah penerimaan $\mathrm{H} 0$ maka dapat disimpulkan secara parsial variabel Indeks Dow Jones berpengaruh signifikan terhadap Indeks Harga Saham Gabungan (IHSG).

Dari perhitungan secara parsial diperoleh nilai $\mathrm{t}$ hitung sebesar .0605 sedangkan nilai sig $(\alpha / 2=0,025)$ dengan degree of freedom (df) 31 (n-k-1) diperoleh nilai $\mathrm{t}$ tabel sebesar 1,695. Dari hasil tersebut diketahui bahwa nilai $\mathrm{t}$ hitung $-0,605<\mathrm{t}$ tabel 1,695 maka H0 diterima dan H1 ditolak, dengan nilai signifikansi 0,550 >0,05. kurva Uji t diatas berada pada daerah penerimaan $\mathrm{H} 0$ maka dapat disimpulkan secara parsial variabel indeks Nikkei 225 tidak berpengaruh signifikan terhadap Indeks Harga Saham Gabungan (IHSG).

\section{B. Pembahasan}

\section{Pengaruh Nilai tukar terhadap Indeks Harga Saham Gabungan}

Variabel nilai tukar secara parsial tidak berpengaruh signifikan terhadap Indeks Harga Saham Gabungan (IHSG) pada periode 2017-2019. Hasil penelitian ini sejalan dengan penelitian yang telah dilakukan oleh i(Marhen \& Yusra, 2019) yang menjelaskan bahwa variabel nilai tukar tidak berpengaruh signifikan terhadap Indeks Harga Saham Gabungan (IHSG). Namun koefisien regresi Nilai Tukar Rupiah bertanda negatif menunjukkan Niai Tukar rupiah berpengaruh negatif terhadap Indeks Harga Saham gabungan (IHSG).

Apabila nilai tukar rupiah terhadap dolar mengalami kenaikan maka IHSG akan mengalami penurunan, sebaliknya jika Nilai Tukar Rupiah terhadap dollar mengalami penurunan maka IHSG akan mengalami peningkatan, tetapi dalam penelitian ini Nilai Tukar Rupiah tidak berpengaruh signifikan terhadap IHSG yang disebabkan investor tidak 
menganggap variabel Nilai Tukar Rupiah sebagai faktor yang mempengaruhi IHSG. penyebab lainnya nilai tukar rupiah tidak signifikan dikarenakan daya beli masyarakat yang masih terjaga, Selain daya beli masyarakat yang masih bagus, juga disebabkan oleh gaya hidup masyarakat menengah ke atas yang terus meningkat. oleh karena itu, daya beli masyarakat dan pertumbuhan ekonomi yang masih stabil bisa mengimbangi fluktuasi kurs (Marhen \& Yusra, 2019).

\section{Pengaruh BI Rate terhadap Indeks Harga Saham Gabungan}

Variabel BI Rate secara parsial tidak berpengaruh signifikan terhadap Indeks Harga Saham Gabungan (IHSG) pada periode 2017-2019. Hasil Penelitian ini sejalan dengan penelitian yang dilakukan oleh (Wibowo et al., 2016). yang menjelaskan bahwa variabel BI Rate tidak berpengaruh signifikan terhadap Indek Harga Saham Gabungan.

Dalam dunia usaha, kendati dana kredit perbankan tersedia beban bunga yang harus mereka tanggung lebih tinggi sehingga dunia usaha cenderung mencari alternatif pendanaan yang lebih murah (Pohan, 2008). Hasil yang tidak signifikan disebabkan karena tipe investor di Indonesia merupakan investor yang senang melakukan transaksi saham dalam jangka pendek (trader/spekulan), sehingga investor cenderung melakukan aksi profit taking dengan harapan memperoleh capital gain yang cukup tinggi di pasar modal dibandingkan berinvestasi di SBI (Manullang, 2008).

\section{Pengaruh Indeks Dow Jones terhadap Indeks Harga Saham Gabungan}

Variabel Indeks Dow Jones berpengaruh signifikan terhadap Indeks Harga Saham Gabungan. Hasil penelitian ini sejalan dengan penelitian yang dilakukan oleh (Sudarsana \& Candraningrat, 2014), (Yusnita Jayanti, 2014), i(Wibowo et al., 2016) (Deitiana \& Stella, 2009) yang menjelaskan bahwa Indeks Dow Jones Berpengaruh postif dan signifikan terhadap Indeks Harga Saham Gabungan (IHSG). Pengaruh positif indeks Dow Jones terhadap IHSG mengindikasikan telah terintegrasinya pasar modal Indonesia dengan pasar modal Amerika Serikat. Selain itu karena Amerika Serikat merupakan salah satu negara tujuan ekspor terbesar di Indonesia seperti ekspor non migas. Membaiknya perekonomian Amerika Serikat akan mempengaruhi perekonomian di Indonesia yang juga akan ikut membaik.

4. Pengaruh Indeks Nikkei 225 Terhadap Indeks Harga Saham Gabungan

Variabel Indeks Nikkei 225 tidak berpengaruh signifikan terhadap Indeks Harga Saham Gabungan (IHSG). Hal ini membuahkan hasil yang sama seperti hasil penelitian dari i(Wibowo et al., 2016) yang menunjukkan bahwa variabel Indeks Nikkei 225 tidak berpengaruh signifikan terhadap Indeks Harga Saham Gabungan. Pasar modal Indonesia sudah terintegrasi dengan pasar modal dunia. Hal ini menimbulkan konsekuensi bahwa pergerakan pasar modal Indonesia akan dipengaruhi oleh pergerakan pasar modal dunia baik secara langsung maupun tidak langsung (Samsul, 2006). 
Perusahaan yang tercatat di Indeks Nikkei 225 merupakan perusahaan besar yang telah beroperasi secara global, termasuk di Indonesia. Dengan naiknya Indeks Nikkei 225 ini berarti kinerja perekonomian Jepang ikut membaik. Sebagai salah satu negara tujuan ekspor Indonesia, pertumbuhan ekonomi Jepang dapat mendorong pertumbuhan ekonomi Indonesia melalui kegiatan ekspor maupun aliran modal masuk baik investasi langsung maupun melalui pasar modal. Ekspor Indonesia yang ternyata lagi tumbuh berbanding terbalik sama jepang yang ternyata ekspor jepang sedang turun pada tahun 2019 maka dari itu Indeks Nikkei 225 tidak berpengaruh signifikan terhadap Indeks Harga Saham Gabungan (IHSG).

\section{Kesimpulan}

Seperti dengan rumusan masalah dan tujuan dari penelitian ini serta hasil analisis yang telah dijabarkan pada bab IV, maka diperoleh kesimpulan sebagai bahwa Variabel nilai tukar yang mempunyai pengaruh terhadap aktivitas di pasar saham maupun di pasar uang karena investor akan berhati-hati untuk melakukan investasi portofolio secara statistika ternyata nilai tukar tidak berkontribusi terhadap Indeks Harga Saham Gabungan (IHSG). Hal ini disebabkan karna daya beli masyarakat yang masih terjaga, Selain daya beli masyarakat yang masih bagus, juga disebabkan oleh gaya hidup masyarakat menengah ke atas yang terus meningkat. oleh karena itu, daya beli masyarakat dan pertumbuhan ekonomi yang masih stabil bisa mengimbangi fluktuasi kurs.

Variabel BI Rate dalam penelitian ini secara statistika Indeks Harga Saham Gabungan (IHSG) tidak terpengaruh oleh BI Rate. Hasil yang tidak signifikan disebabkan karena tipe investor di Indonesia merupakan investor yang senang melakukan transaksi saham dalam jangka pendek (trader/spekulan), sehingga investor cenderung melakukan aksi profit taking dengan harapan memperoleh capital gain yang cukup tinggi di pasar modal dibandingkan berinvestasi di SBI

Variabel Indeks Dow Jones dalam penelitian ini secara statistika berpengaruh signifikan terhadap Indeks Harga Saham Gabungan (IHSG). Pengaruh positif Indeks Dow Jones terhadap IHSG mengindikasikan telah terintegrasinya pasar modal Indonesia dengan pasar modal Amerika Serikat. Amerika Serikat yang merupakan salah satu negara tujuan ekspor terbesar di Indonesia seperti ekspor non migas. Membaiknya perekonomian Amerika Serikat akan mempengaruhi perekonomian di Indonesia yang juga akan ikut membaik.

Variabel Indeks Nikkei 225 dalam penelitian ini secara statistika tidak berpengaruh signifikan terhadap Indeks Harga Saham Gabungan (IHSG). Indeks Nikkei 225 tidak berpengaruh terhadap Indeks Harga Saham Gabungan dikarenakan ekspor Jepang yang menurun sehigga pertumbuhan ekonomi Jepang ikut menurun berbalik arah dengan pertumbuhan ekonomi Indonesia yang sedang naik. Dengan pertumbuhan ekonomi Jepang turun maka Indeks Nikkei 225 juga ikut turun. 
Farhan Hardianto Putra, Marseto dan Sishadiyati

\section{BIBLIOGRAFI}

Agus, I. Wayan, Utama, Budi, Gede, Luh, \& Artini, Sri. (2015). Pengaruh Indeks Bursa Dunia Pada Indeks Harga Saham Gabungan Bursa Efek Indonesia. Jurnal Manajemen, Strategi Bisnis Dan Kewirausahaan, 9(1), 65-73.Google Scholar

Amin, M. (2012). Pengaruh Tingkat Inflasi,Suku Bunga SBI,Nilai krs Dolar dan Indeks dow Jones Terhadap Indeks Harga Saham Gabungan di BEI.

Arifin, Tri Moch. (2014). Pengaruh Inflasi, Suku Bunga Sbi, Perubahan Kurs, Dan Standard \& Poor's 500 Terhadap Indeks Harga Saham Gabungan (Ihsg). Universitas Negeri Yogyakarta. Google Scholar

Bagus Setiawan, Yudhi. (2014). Analisis Integrasi Pasar Saham Amerika ( Djia), Jepang (Nikkei 225), Singapura (Sti), Malaysia (Klse), Thailand (Set) Dan Filipina (Pse) Terhadap Pasar Saham Indonesia. (Nikkei 225). Google Scholar

Bodie, Kane, \& Marcus. (2014). Investment. Tenth Edition. New York: McGraw-Hill Education.

Deitiana, Tita, \& Stella, Stella. (2009). engaruh Indeks Dow Jones, Nikkei 225, Kospi, dan Shanghai Composite Index terhadap Indeks Harga Saham Gabungan Bursa Efek Indonesia Periode Tahun 2004-2008. The Winners, 10(1), 22-30. Google Scholar

Ernayani, Rihfenti. (2015). Pengaruh Kurs Dolar, Indeks Dow Jones Dan Tingkat Suku Bunga SBI Terhadap IHSG (Periode Januari 2005 - Januari 2015). JST (Jurnal Sains Terapan), 1(2), 108-115. Google Scholar

Ghozali, Imam. (2016). Aplikasi Analisis Multivariete Dengan Program IBM SPSS 23 (Edisi 8). Cetakan ke VIII. Badan Penerbit Universitas Diponegoro.Google Scholar

Hasyim, Hariza Riza. (2019). Analisis Faktor-Faktor yang Mempengaruhi Perubahan Nilai Tukar di Indonesia Tahun 2006-2018. Jurnal Al-Iqtishad, 15(1), 1. Google Scholar

Jayanti, Y. (2014). Pengaruh Tingkat Inflasi, Tingkat Suku Bunga Sbi, Nilai Tukar Rupiah, Indeks Dow Jones, Dan Indeks Klse Terhadap Indeks Harga Saham Gabungan (IHSG) Studi Pada Bursa Efek Indonesia Periode Januari 2010 â Desember 2013. Jurnal Administrasi Bisnis S1 Universitas Brawijaya, 11(1), 82780.Google Scholar

Jayanti, Yusnita. (2014). Pengaruh Tingkat Inflasi, Tingkat Suku Bunga SBI, Nilai Tukar Rupiah, Indeks Dow Jones, Dan Indeks Klse Terhadap Indeks Harga Saham Gabungan (Ihsg) Studi Pada Bursa Efek Indonesia Periode Januari 2010-Desember 2013. Jurnal Administrasi Bisnis, 11(1).Google Scholar

Manullang. (2008). Dasar-Dasar Manajemen. Yogyakarta: Ghalia Indonesia. 
Marhen, Apub, \& Yusra, Irdha. (2019). Pengaruh Tingkat Inflasi,Tingkat Suku Bunga, Dan Nilai Tukar Rupiah Terhadap Indeks Harga Saham Gabungan (IHSG) Di Bursa Efek Indonesia. Manajemen Bisnis, 6(2), 1-10. Google Scholar

Nachrowi, D. N., \& Usman, Hardius. (2005). Ekonometrika Untuk Analisis Ekonomi dan Keuangan, Jakarta: LPFEUL. Penerbit: Fakultas Ekonomi Universitas Indonesia.Google Scholar

Nurhayati, Sri Puspa, Mardani, Ronny Malavia, \& Mustapita, Arini Fitria. (2020). Pengaruh Kurs Dollar, Indeks Dow Jones dan Tingkat Suku Bunga Sertifikat Bank Indonesia (SBI) Terhadap Indeks Harga Saham gabungan (IHSG)(Periode 20162018). Jurnal Ilmiah Riset Manajemen, 9(05). Google Scholar

Pohan, Aulia. (2008). Ekonomi Moneter. Buku II. Edisi 1. Cetakan kesepuluh. Yogyakarta: BPFE UGM.Google Scholar

Samsul, Mohamad. (2006). Pasar Modal dan Manajemen Portofolio. Surabaya: Erlangga. Google Scholar

Sudarsana, NMAD, \& Candraningrat, Ica Rika. (2014). Pengaruh Suku Bunga SBI, Nilai Tukar, Inflasi Dan Indeks Dow Jones Terhadap Indeks Harga Saham Gabungan Di BEI. E-Jurnal Manajemen Universitas Udayana, 3(11), 3291-3308. Google Scholar

Utama, IWAB, \& Artini, Luh Gede Sri. (2015). Pengaruh Indeks Bursa Dunia pada Indeks Harga Saham Gabungan Bursa Efek Indonesia. Jurnal Manajemen, Strategi Bisnis Dan Kewirausahaan, 9(1), 65-73. Google Scholar

Wibowo, Feri, Arifati, Rina, \& Raharjo, Kharis. (2016). Analisis Pengaruh Tingkat Inflasi, Suku Bunga Sbi, Nilai Tukar Us Dollar Pada Rupiah, Jumlah Uang Beredar, Indeks Dow Jones, Indeks Nikkei 225, Dan Indeks Hangseng Terhadap Pergerakan Indeks Harga Saham Gabungan (Ihsg) Periode Tahun 2010-2014. Journal Of Accounting, 2(2). Google Scholar

\section{Copyright holder :}

Farhan Hardianto Putra, Marseto, Sishadiyati (2021)

First publication right :

Syntax Idea

\section{This article is licensed under:}

